\title{
Facile Fabrication of Multifunctional ZnO Urchins on Surfaces
}

\author{
Abinash Tripathy 1,2®D, Patryk Wąsik 1,3®D, Syama Sreedharan ${ }^{4}$, Dipankar Nandi ${ }^{4}$, \\ Oier Bikondoa ${ }^{5,6} \mathbb{D}^{\mathrm{D}}$, Bo Su ${ }^{7}$, Prosenjit Sen ${ }^{2}$ and Wuge H. Briscoe ${ }^{1, *(\mathbb{D}}$ \\ 1 School of Chemistry, University of Bristol, Cantock's Close, Bristol BS8 1TS, UK; \\ atripathy8@gmail.com (A.T.); pw13934@bristol.ac.uk (P.W.) \\ 2 Centre for Nano Science and Engineering, Indian Institute of Science, Bangalore 560012, India; \\ prosenjits@iisc.ac.in \\ 3 Bristol Centre for Functional Nanomaterials (BCFN), HH Wills Physics Laboratory, University of Bristol, \\ Tyndall Avenue, Bristol BS8 1TL, UK \\ 4 Department of Biochemistry, Indian Institute of Science, Bangalore 560012, India; \\ syama.micro2013@gmail.com (S.S.); nandi@iisc.ac.in (D.N.) \\ 5 XMas, The UK CRG Beamline at the ESRF, The European Synchrotron, 71, avenue des Martyrs, CS 40220, \\ 38043 Grenoble CEDEX 9, France; oier.bikondoa@esrf.fr \\ 6 Department of Physics, University of Warwick, Gibbet Hill Road, Coventry CV4 7AL, UK \\ 7 Bristol Dental School, University of Bristol, Bristol BS1 2LY, UK; b.su@bristol.ac.uk \\ * Correspondence: wuge.briscoe@bristol.ac.uk
}

Received: 19 November 2018; Accepted: 10 December 2018; Published: 14 December 2018

\begin{abstract}
Functional $\mathrm{ZnO}$ nanostructured surfaces are important in a wide range of applications. Here we report the simple fabrication of $\mathrm{ZnO}$ surface structures at near room temperature with morphology resembling that of sea urchins, with densely packed, $\mu \mathrm{m}$-long, tapered nanoneedles radiating from the urchin center. The $\mathrm{ZnO}$ urchin structures were successfully formed on several different substrates with high surface density and coverage, including silicon (Si), glass, polydimethylsiloxane (PDMS), and copper ( $\mathrm{Cu}$ ) sheets, as well as Si seeded with $\mathrm{ZnO}$ nanocrystals. Time-resolved SEM revealed growth kinetics of the $\mathrm{ZnO}$ nanostructures on $\mathrm{Si}$, capturing the emergence of "infant" urchins at the early growth stage and subsequent progressive increases in the urchin nanoneedle length and density, whilst the spiky nanoneedle morphology was retained throughout the growth. $\varepsilon-\mathrm{Zn}(\mathrm{OH})_{2}$ orthorhombic crystals were also observed alongside the urchins. The crystal structures of the nanostructures at different growth times were confirmed by synchrotron X-ray diffraction measurements. On seeded Si substrates, a two-stage growth mechanism was identified, with a primary growth step of vertically aligned $\mathrm{ZnO}$ nanoneedle arrays preceding the secondary growth of the urchins atop the nanoneedle array. The antibacterial, anti-reflective, and wetting functionality of the $\mathrm{ZnO}$ urchins-with spiky nanoneedles and at high surface density - on Si substrates was demonstrated. First, bacteria colonization was found to be suppressed on the surface after $24 \mathrm{~h}$ incubation in gram-negative Escherichia coli (E. coli) culture, in contrast to control substrates (bare Si and Si sputtered with a $20 \mathrm{~nm} \mathrm{ZnO}$ thin film). Secondly, the ZnO urchin surface, exhibiting superhydrophilic property with a water contact angle $\sim 0^{\circ}$, could be rendered superhydrophobic with a simple silanization step, characterized by an apparent water contact angle $\theta$ of $159^{\circ} \pm 1.4^{\circ}$ and contact angle hysteresis $\Delta \theta<7^{\circ}$. The dynamic superhydrophobicity of the surface was demonstrated by the bouncing-off of a falling $10 \mu \mathrm{L}$ water droplet, with a contact time of 15.3 milliseconds (ms), captured using a high-speed camera. Thirdly, it was shown that the presence of dense spiky $\mathrm{ZnO}$ nanoneedles and urchins on the seeded Si substrate exhibited a reflectance $R<1 \%$ over the wavelength range $\lambda=200-800 \mathrm{~nm}$. The $\mathrm{ZnO}$ urchins with a unique morphology fabricated via a simple route at room temperature, and readily implementable on different substrates, may be further exploited for multifunctional surfaces and product formulations.
\end{abstract}


Keywords: ZnO urchins; nanostructured surfaces; E. coli; superhydrophilic; superhydrophobic; anti-reflective surfaces

\section{Introduction}

Nanostructured surfaces are widespread in nature and many are ingeniously multifunctional. This has inspired considerable effort in the fabrication of hierarchical surface nanotextures. For instance, lotus leaf inspired nanostructures on silicon, $\mathrm{TiO}_{2}$, and polymer surfaces exhibit superhydrophobic, self-cleaning and antibacterial characteristics [1-5]. Nanostructured surfaces on silicon and glass substrates mimicking cicada/dragonfly wings or moth eyes possess superhydrophobic and antimicrobial characteristics, as well as gradient refractive indices for anti-reflective applications [6-11].

Surfaces bearing $\mathrm{ZnO}$ nanostructures are among the most widely studied, with a wide range of applications in gas and bio-sensing, field emission devices, ultraviolet detectors, and photovoltaics [12] due to their thermostability [13], low-cost production [14], antimicrobial properties [15-19], and biocompatibility [20]. Several fabrication methods of $\mathrm{ZnO}$ nanostructured surfaces have been reported [21-28], such as hydrothermal synthesis, laser ablation, sputtering, thermal decomposition, evaporation induced self-assembly [29,30], and the sol-gel technique. Various $\mathrm{ZnO}$ nanostructures that have been reported include one-dimensional (1-D) morphologies such as nanowires [31-33], nanofibers [29,30], nanorods [34-37], micro-dendrites [38,39], and nanotubular structures [40-44], as well as 3-D architectures such as flowers/urchins [45-50], tetrapods/jack-like [51,52], and hedgehogs [53]. The 3-D nanostructures with enhanced surface area may be used as substitutes for 1-D nanostructure arrays with enhanced functionalities, but their fabrication requires either sophisticated instrumentation or elevated temperatures (and thus high energy input).

Here, we report the simple fabrication of multifunctional 3-D ZnO urchins on silicon ( $\mathrm{Si}$ ) substrates in a solution-based synthesis at near room temperature (RT) using a one-step procedure, which could also be applied on $\mathrm{Si}$ substrates seeded with $\mathrm{ZnO}$ crystals and various other substrates. The morphology of these $\mathrm{ZnO}$ surface structures resembles that of sea urchins, with tapered nanoneedles $\mu \mathrm{m}$ in length radiating from a central core. The growth kinetics of the $\mathrm{ZnO}$ urchins were studied by examining their intermediate morphologies at different growth time intervals (0.5-12 h). The $\mathrm{ZnO}$ urchin-coated surface exhibited high anti-reflectance, and superhydrophobicity after silanization, as investigated by contact angle, contact angle hysteresis and drop impact analyses. They were also bacteriophobic against Escherichia coli (E. coli). This simple fabrication method for $\mathrm{ZnO}$ urchins could also be adapted for a variety of materials such as polydimethylsiloxane (PDMS), copper sheets and glass substrates, demonstrating its versatility.

\section{Materials and Methods}

\subsection{Substrate Preparation and Cleaning}

Silicon substrates were prepared by cutting a silicon wafer (100 mm diameter, P type, B dopant, $<100>, 1-100 \Omega \cdot \mathrm{cm}, 500 \mu \mathrm{m}$ thick, single-sided polish, test grade, University Wafer, Inc., South Boston, MA, USA) into $1 \mathrm{~cm} \times 1 \mathrm{~cm}$ squares. All substrates, including copper sheet, glass slide (Polar Industrial Corporation, Mumbai, India) and polydimethylsiloxane (Dow Corning, Sylgard 184, Cardiff, UK) were cleaned by a subsequent sonication in acetone, ethanol, and deionized water (10 $\mathrm{min}$ in each) followed by drying with $\mathrm{N}_{2}$.

\subsection{Seeding}

A seeding procedure was used to produce nucleation sites for the growth of $\mathrm{ZnO}$ nanostructures [31]. Cleaned silicon substrates were dipped in a solution of zinc acetate dihydrate $\left(\mathrm{Zn}\left(\mathrm{CH}_{3} \mathrm{COO}\right)_{2} \cdot 2 \mathrm{H}_{2} \mathrm{O}, 99 \%\right.$, Sigma Aldrich, Dorset, UK) in ethanol $\left(\mathrm{CH}_{3} \mathrm{CH}_{2} \mathrm{OH}\right.$, Absolute, 
Sigma Aldrich) for a few seconds, rinsed with clean ethanol and then dried with $\mathrm{N}_{2}$. This coating step was repeated 5 times for each seeded silicon substrate (see Figure S1). Subsequently, the substrates were heated to $300{ }^{\circ} \mathrm{C}$ on a hot plate, and annealed for $30 \mathrm{~min}$ in air to thermally decompose zinc acetate crystallites to $\mathrm{ZnO}$ islands with (0001) planes parallel to the silicon substrate surface [31].

\section{3. $\mathrm{ZnO}$ Urchin Growth}

To grow the $\mathrm{ZnO}$ nanostructures, $50 \mathrm{~mL}$ aqueous solution of zinc nitrate hexahydrate $\left(\mathrm{Zn}\left(\mathrm{NO}_{3}\right)_{2} \cdot 6 \mathrm{H}_{2} \mathrm{O}, 98 \%\right.$, Sigma Aldrich) solution was added dropwise to $50 \mathrm{~mL}$ of potassium hydroxide (KOH, 85\%, Fisher Scientific) aqueous solution under constant stirring for $30 \mathrm{~min}$. Next, the alkali solution of zincate ions was carefully poured into the glass Petri dish containing substrates (seeded Si, non-seeded $\mathrm{Si}, \mathrm{Cu}$ sheet, glass and polydimethylsiloxane, separately for each type) sealed with a glass lid and a paraffin film, and kept at $20^{\circ} \mathrm{C} \pm 2{ }^{\circ} \mathrm{C}$ for $12 \mathrm{~h}$. After the synthesis, samples were rinsed with Deionized (DI) water and dried with $\mathrm{N}_{2}$.

\subsection{Bacterial Growth Conditions and Sample Preparation}

Isolated single colonies of E. coli K-12 (MG 1655) were used to prepare the pre-inoculum [54]. The culture was grown in Luria Bertani (LB) medium for $8 \mathrm{~h}$ at $37{ }^{\circ} \mathrm{C}$ with constant shaking at $160 \mathrm{rpm}$. A $0.2 \%$ pre-inoculum was added into $10 \mathrm{~mL}$ of LB medium and was allowed to grow to 0.3 optical density (O.D.) at $600 \mathrm{~nm}$ [55]. The cells were subsequently pelleted and washed with phosphate-buffered saline (PBS). A cell suspension of 0.01 O.D. at $600 \mathrm{~nm}$ was used for studying the bacterial interaction with the bare, unmodified silicon, silicon with a $20 \mathrm{~nm}$ thin film of $\mathrm{ZnO}$, and $\mathrm{ZnO}$ nanourchin surfaces.

\subsection{Scanning Electron Microscopy (SEM)}

$\mathrm{ZnO}$ nanostructured surfaces were imaged using field emission scanning electron microscopy (JSM-IT300 SEM (JEOL)). Dimensions of the ZnO nanourchin-like structures were obtained from the SEM images using ImageJ software. For bacterial sample imaging, substrates were first washed with PBS to remove the loosely adhered cells. Substrates were then dipped in $2.5 \%$ of glutaraldehyde to fix the cells. After that all the substrates were allowed to dry in a vacuum. A thin layer of gold $(15 \mathrm{~nm})$ was sputtered on the samples using a Quorum sputter coater (Q150T) to avoid the charging effect while doing the SEM. Samples were scanned thoroughly using SEM (sample size $1.3 \mathrm{~cm} \times 1.3 \mathrm{~cm}$ ) and the imaging was done in triplicate for all the samples. Selecting three specimens from each type of sample (two controls and one $\mathrm{ZnO}$ Urchin surface) ensured the repeatability.

\subsection{Urchin Dimension Analysis}

ImageJ [56] was used to obtain the morphological information of the nanoneedles comprising the $\mathrm{ZnO}$ urchin and the vertical nanoneedles, using the length and angle measurement tools.

\subsection{X-ray Diffraction (XRD)}

The presence of crystalline $\mathrm{ZnO}$ after the growth procedure was confirmed using D8 Advance Bruker-AXS diffractometer $\left(\mathrm{Cu} \mathrm{K} \alpha\right.$ radiation $(\lambda=0.154178 \mathrm{~nm}), \theta-2 \theta$ scan, $2 \theta=10^{\circ}-90^{\circ}$, step size $-0.02(2 \theta)$, step count $-1.5 \mathrm{~s})$.

\subsection{Grazing Incidence X-ray Diffraction (GIXRD)}

GIXRD analysis of the seeded and non-seeded silicon substrates used to study the time dependence growth of $\mathrm{ZnO}$ nanostructures, was performed at Beamline BM28 at the European Synchrotron Radiation Facility (France). Experimental parameters: radiation wavelength: $0.8856 \AA$, sample to detector distance: $0.24 \mathrm{~m}$, detector: MAR165, calibrant: silver behenate and ZnO powder. 
The diffraction patterns were reduced to one-dimensional line profiles using $p y F A I$, a pythonic library for 1D azimuthal/2D radial integrations of diffraction images [57].

\subsection{Contact Angle Measurement and High-Speed Imaging}

Apparent contact angle [58-60] measurements were carried out using a Krüss Drop Shape Analyser (DSA 100). A $10 \mu \mathrm{L}$ water droplet was placed gently on all the substrates to measure the contact angles. A custom-made goniometer setup was used to measure the contact angle hysteresis. The stage of the goniometer was tilted, and the droplet image was captured when the droplet first started to slide to measure the contact angle hysteresis. The advancing and receding contact angles were measured from the droplet image using ImageJ software. The contact angle hysteresis was obtained by calculating the difference between the advancing and receding contact angles. All the measurements were repeated three times. Droplet impact dynamics of water droplet on the superhydrophobic surface (silanized seeded silicon substrate with $\mathrm{ZnO}$ nanostructures) were captured using a high-speed camera (Photron FastCam SA4) at 10,000 fps (time resolution of $0.1 \mathrm{~ms}$ ). The droplets were created by a micro-pipette and released from a height of $7 \mathrm{~cm}$ (Weber number)

$$
(W e)=\frac{\text { inertial force }}{\text { surface tension force }}=\frac{\rho V^{2} D_{w}}{\gamma}=\frac{1000 \times 1.17^{2} \times 0.0026}{0.072}=49,
$$

Density of water $(\rho)=1000 \frac{\mathrm{kg}}{\mathrm{m}^{3}}$, Velocity of falling droplet $(V)=\sqrt{2 g h}=1.17 \frac{\mathrm{m}}{\mathrm{s}}$, Surface tension of water $(\gamma)=0.072 \frac{\mathrm{N}}{\mathrm{m}}$, and diameter of droplet $\left.\left(D_{w}\right)=0.0026 \mathrm{~m}\right)$.

\subsection{Reflectance Measurements}

To calculate the reflectance of all the surfaces, a Shimadzu MPC3600 UV-VIS-NIR Spectrometer with an absolute specular reflectance mode was used. Wavelengths ranging from $200 \mathrm{~nm}$ to $800 \mathrm{~nm}$ were used for the reflectance measurement. A $D_{2}$ light source was used for the range $200-310 \mathrm{~nm}$ and a Tungsten source was used for the range 310-800 nm. The angle of incidence and angle of reflection were set to $5^{\circ}$ throughout the experiment. The equipment used a photomultiplier tube (PMT) detector. The reflectance from a surface is evaluated by its refractive index profile [6]. In general, a flat surface has a high reflectance due to the discontinuous refractive index profile, whereas a structured surface suppresses reflection with its graded refractive index profile [6].

\section{Results and Discussion}

Figure 1 shows the SEM images of densely packed urchins after growth in $5 \mathrm{mM}$ zincate solution on a seeded silicon substrate (Figure S2) at $\sim 20^{\circ} \mathrm{C}$ for $12 \mathrm{~h}$, and the simple fabrication method is described in Figure S1. XRD (Figure S11) confirmed that these urchins were ZnO. The morphology of an individual urchin (Figure 1c) revealed sharply tapered needles radiating from the center. The length of the needles was $L \sim 1.65 \pm 0.11 \mu \mathrm{m}$, its width at the central base was $D_{\mathrm{c}} \sim 156 \pm 24 \mathrm{~nm}$ and at the tip $D_{\mathrm{t}} \sim 13 \pm 7 \mathrm{~nm}$, with a tapering angle $\theta \sim 10^{\circ}$ and an average tip-to-tip spacing $s \sim 504 \pm 119 \mathrm{~nm}$ (see Figures S3-S5 for the size distribution analysis).

Previously, ZnO nano- and micro-structures resembling the urchin morphology have been reported. For instance, Elias et al. [50] prepared $\mu \mathrm{m}$-sized hollow spheres with a $\mathrm{ZnO}$ nano-columns coating using atom layer deposition and electrodeposition, whilst the method by Shen et al. [49] used thermos-evaporation of metallic $\mathrm{Zn}$ powder at high temperature $\left(\sim 750{ }^{\circ} \mathrm{C}\right)$. Wahab et al. [45] fabricated $\mathrm{ZnO}$ nano-flowers with blunt tapering via $\mathrm{pH}$-controlled reactions in a solution of zinc acetate dihydrate and sodium hydroxide at $90{ }^{\circ} \mathrm{C}$. Using a similar approach, Gokarna et al. [46] synthesised $\mathrm{ZnO}$ urchin-like structures with columnar nanoneedles. Hieu et al. [47] sputtered zinc onto a polystyrene-sphere array and subsequent oxidation at $500{ }^{\circ} \mathrm{C}$ led to columnar $\mathrm{ZnO}$ urchins; while the method used by Taheri et al. [48] also involved depositing zinc acetate dihydrate precursor followed by calcination at $500{ }^{\circ} \mathrm{C}$. The solution synthesis method we report here is relatively simpler (at RT and applicable to different surfaces as we show below) compared to these previous studies, producing 
spiky tapered morphology of the urchin needles with a very high density previously unreported. The presence of high-density spiky $\mathrm{ZnO}$ urchins endows the surface with multi-functionalities as discussed below.

SEM images of the region not covered by the urchins reveal vertical $\mathrm{ZnO}$ nanoneedles (from the primary growth step as referred to in Figure $1 \mathrm{~d}, \mathrm{~g}$ ) with an average base diameter $\sim 90 \pm 20 \mathrm{~nm}$, smaller than that of the urchin needles (Figure $1 \mathrm{~d}-\mathrm{g}$ ), and the cross-section SEM view confirms that the $\mathrm{ZnO}$ urchins were formed atop a layer of nanoneedle arrays (Figure 1a,b). Orthorhombic $\varepsilon-\mathrm{Zn}(\mathrm{OH})_{2}$ crystals with facet edges $\sim 10-30 \mu \mathrm{m}$ were also observed (Figure S7), with $\mathrm{ZnO}$ urchins (the secondary growth in Figure 1d) decorating the facets. The tapered or spiky nanoneedle geometry might be attributed to the concentration gradient of the zinc ions in the vicinity of the substrate where the $\mathrm{ZnO}$ nanocrystal seeds provided the nucleation sites for $\mathrm{ZnO}$ nanoneedle growth (Figure 1f,g) [61].
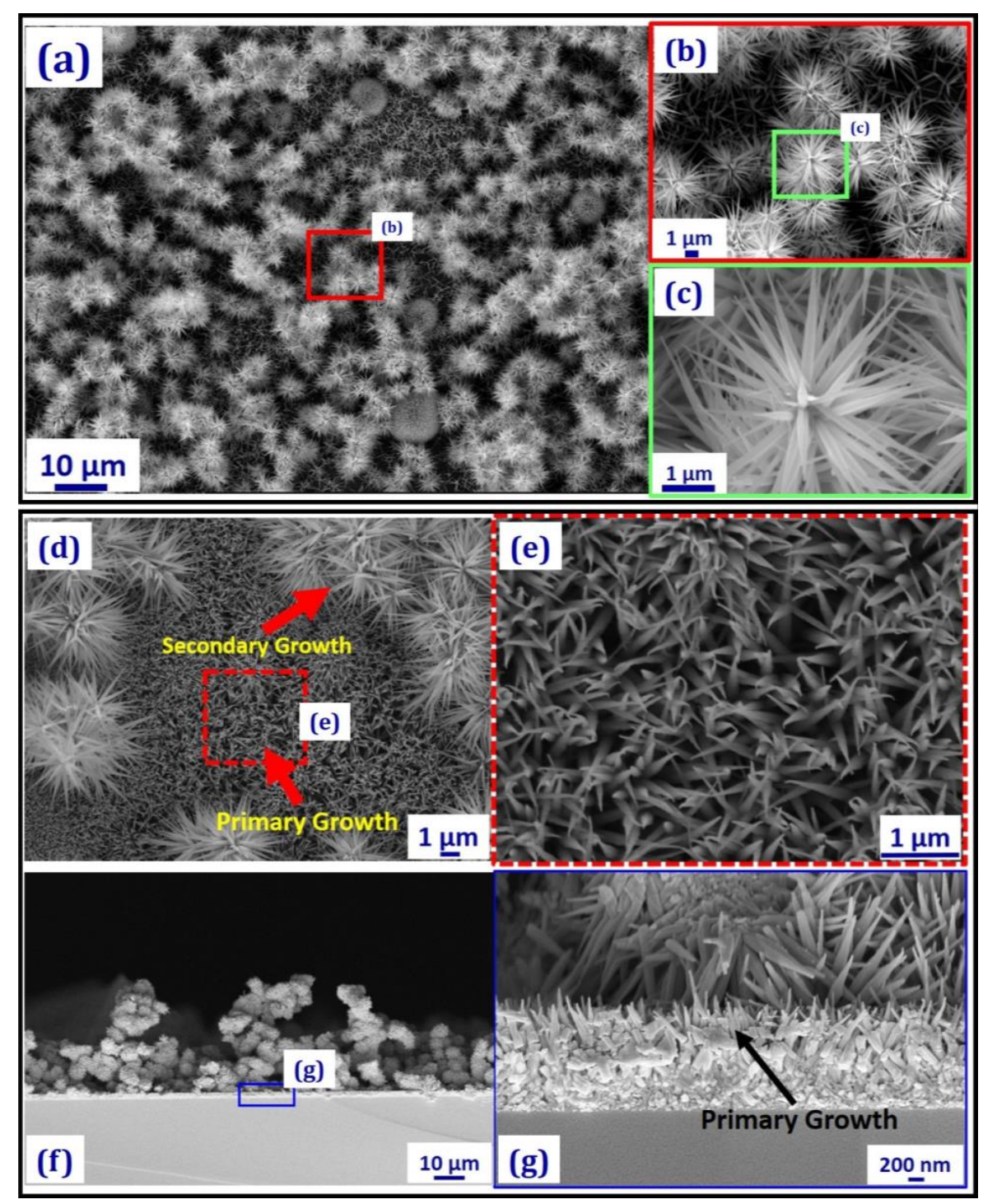

Figure 1. Scanning electron microscopy (SEM) images of $\mathrm{ZnO}$ urchins on a seeded silicon substrate (a), and SEM images of the region not covered by the urchins revealing vertical $\mathrm{ZnO}$ nanoneedles from the primary growth $(\mathbf{d}, \mathbf{g})$, with enlarged views shown in $(\mathbf{b}, \mathbf{c}, \mathbf{e}, \mathbf{f})$ respectively. (Seeding concentration of zinc acetate dihydrate $-5 \mathrm{mM}$, synthesis time for $\mathrm{ZnO}$ urchin growth $-12 \mathrm{~h}$, and temperature $-20^{\circ} \mathrm{C}$ ).

To understand the growth kinetics of the ZnO nanostructures, SEM images (Figure 2, Figures S8 and S9) of the seeded silicon substrates were taken at different growth time intervals, $t$. At $t=0.5-1$ 
$\mathrm{h}$ (Figure 2a,b), only the primary growth of vertical nanoneedle structures was observed. At $t=3 \mathrm{~h}$, the secondary growth of urchin-like structures atop the nanoneedle array with a diameter $\varphi \sim 1 \mu \mathrm{m}$ was observed. The density and size of the urchins and length of the urchin needle, $L$, then increased with time (see Figure S5 for urchin needle length, $L$ vs. growth time, $t$ ), whilst the tapering angle remained largely constant at $\theta \sim 10^{\circ}$. Figure $2 \mathrm{~g}$ presents the GIXRD data (see Section 2.8 in Materials and Methods) on the seeded silicon substrates at different growth time intervals. The intense (002) $\mathrm{ZnO}$ peak at $t<3 \mathrm{~h}$ is consistent with the primary growth of vertical $\mathrm{ZnO}$ nanoneedles. The $\varepsilon-\mathrm{Zn}(\mathrm{OH})_{2} \mathrm{phase}$ (orthorhombic crystals) is visible for the samples with a reaction time $t>3 \mathrm{~h}$ (Figure $2 \mathrm{~g}$ ). This shows that the $\mathrm{ZnO}$ nanoneedles started forming after $30 \mathrm{~min}$ and $\mathrm{Zn}(\mathrm{OH})_{2}$ crystals after $3 \mathrm{~h}$, likely together with the secondary growth of $\mathrm{ZnO}$ urchins (Figure 2c-f).
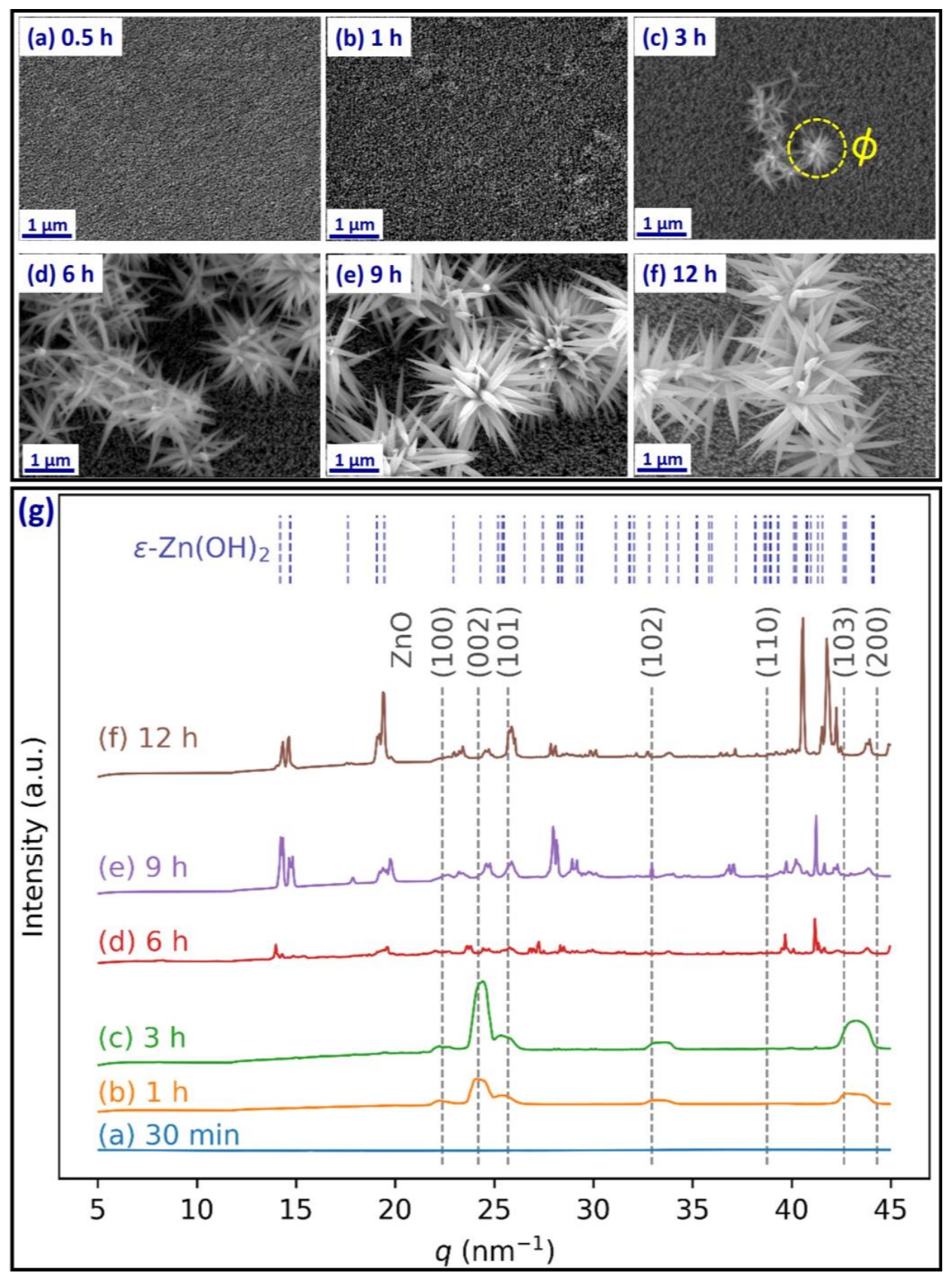

Figure 2. (a-f) SEM images of seeded silicon substrates in $5 \mathrm{mM}$ zincate growth solution at different growth time intervals, $t=0.5-12 \mathrm{~h}$; and (g) corresponding GIXRD data for the substrates. 
To evaluate the effect of substrate seeding on the $\mathrm{ZnO}$ urchin morphology, the one-step fabrication procedure was performed using unseeded silicon substrates (i.e., in $5 \mathrm{mM}$ zincate solution at $20^{\circ} \mathrm{C}$, and $12 \mathrm{~h}$ growth time). The SEM image in Figure 3a shows that urchin-like $\mathrm{ZnO}$ nanostructures were also obtained with a high surface coverage (Figure 3a,c), with urchins found on orthorhombic $\varepsilon-\mathrm{Zn}(\mathrm{OH})_{2}$ crystal facets (Figure $\left.3 \mathrm{~b}\right)$. There was no significant difference in the urchin morphology (urchin size, $\varphi$; needle length, $L$; diameter, $D$; and tip angle, $\theta$ ) compared to the seeded substrate. However, some urchins in the bare silicon area had a smaller number of nanoneedles (Figure $3 \mathrm{~d}$ ). Comparison of the XRD patterns in Figure S11 for $12 \mathrm{~h}$ growth shows that on the unseeded Si sample, the most intense peaks correspond to the $\varepsilon-\mathrm{Zn}(\mathrm{OH})_{2}$ crystal structure, consistent with the SEM images shown in Figure 3.
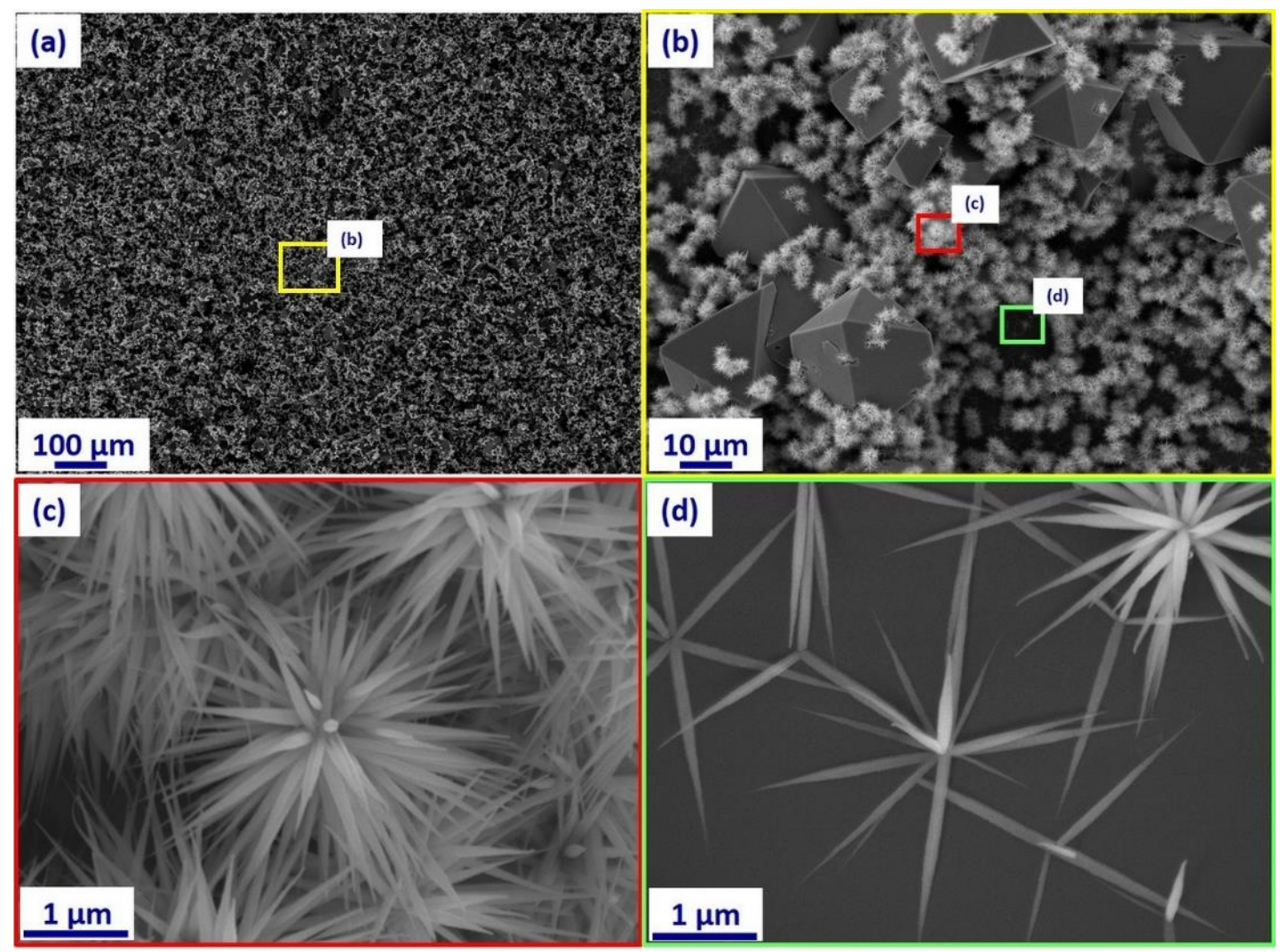

Figure 3. SEM images of $\mathrm{ZnO}$ nanostructures grown on the unseeded silicon substrate in the one-step synthesis $\left(12 \mathrm{~h}, 20^{\circ} \mathrm{C}\right)$, with a high coverage of $\mathrm{ZnO}$ urchins (a) and with morphology similar to that on seeded Si substrates $(\mathbf{b}, \mathbf{c})$. Orthorhombic $\varepsilon-\mathrm{Zn}(\mathrm{OH})_{2}$ crystals were also observed $(\mathbf{b})$ decorated with urchins. Urchins with a smaller number of needles were also observed in the bare silicon area (d).

Time dependent growth of $\mathrm{ZnO}$ urchins on non-seeded silicon substrate was also studied, and SEM images at different growth time intervals are shown in Figure S10. Similar to the seeded Si substrates, $\mathrm{ZnO}$ urchins emerged between $1-3 \mathrm{~h}$ of growth time (Figure S10a,e). Their dimensions and surface coverage increased with time (Figure S10), with orthorhombic $\varepsilon-\mathrm{Zn}(\mathrm{OH})_{2}$ crystals starting to appear on the surface between 3-6 h of the synthesis (Figure S10b,h).

Figure S11 further compares the XRD on both seeded and non-seeded silicon substrates after growth in the zincate solution for $12 \mathrm{~h}$. Peaks corresponding to both $\mathrm{ZnO}$ (PDF 36-1451) and $\varepsilon-\mathrm{Zn}(\mathrm{OH})_{2}$ (PDF 38-385) were identified, confirming their formation on the surfaces. The most intense peak in the seeded silicon sample corresponds to the $\mathrm{ZnO}(002)$ plane, which is the preferential growth direction of $\mathrm{ZnO}$ nanoneedles [62]. Along with the SEM images, this confirms that on seeded Si the primary growth led to $\mathrm{ZnO}$ nanoneedles, with the $\mathrm{ZnO}$ urchins grown atop these in the secondary growth 
stage. In the case of the unseeded Si sample, the most intense peaks correspond to the $\varepsilon-\mathrm{Zn}(\mathrm{OH})_{2}$ crystal structure. This is consistent with the SEM image (Figure 3b) which shows that the substrate was covered by $\mathrm{ZnO}$ urchins grown on orthorhombic $\mathrm{Zn}(\mathrm{OH})_{2}$ crystals and bare Si surface, with a significantly smaller number of arrayed $\mathrm{ZnO}$ nanoneedles (Figure 3d).

Growth of the $\mathrm{ZnO}$ nanoneedles and urchin structures was also trialed on copper sheets, soft PDMS and transparent glass substrates, all seeded by dipping the substrates in a solution of zinc acetate dihydrate in ethanol (Figure S1). The $\mathrm{ZnO}$ nanostructures grown on these surfaces (Figure 4g-i) exhibited similar urchin morphologies to the those on silicon substrates (Figure 1). The growth on glass was also evident, as it became translucent after the growth (Figure $4 \mathrm{~d}$ and Figure S12). This demonstrated that the simple, room temperature synthesis method for $\mathrm{ZnO}$ nanoneedles and urchins is adaptable to various substrates.

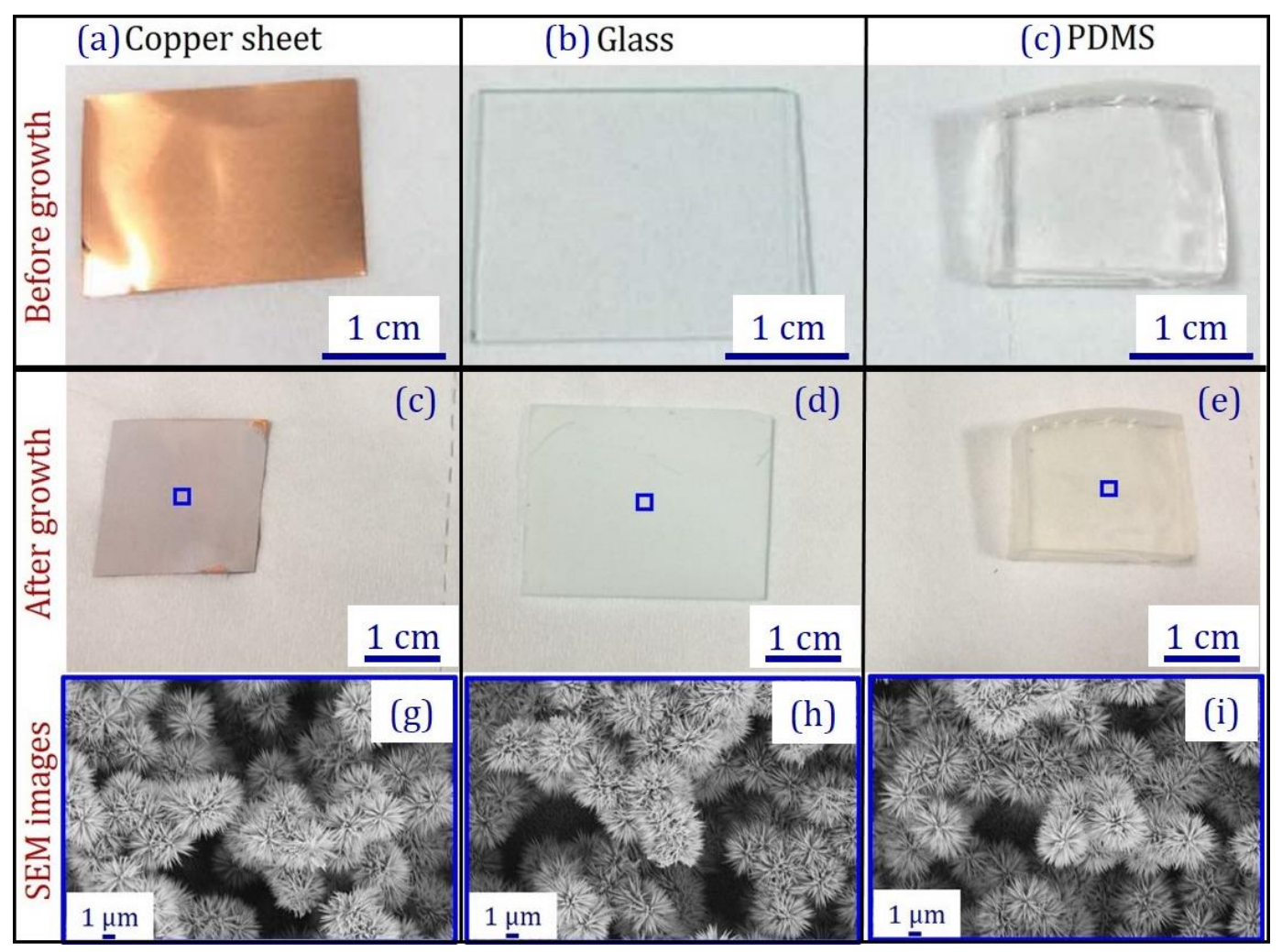

Figure 4. Photos of seeded substrates before and after growth of $\mathrm{ZnO}$ urchins, and corresponding SEM images of the $\mathrm{ZnO}$ urchins formed on the substrates: $(\mathbf{a}, \mathbf{c}, \mathbf{g})$ copper, $(\mathbf{b}, \mathbf{d}, \mathbf{h})$ glass slide, and $(\mathbf{c}, \mathbf{e}, \mathbf{i})$ polydimethylsiloxane (PDMS) surfaces.

Si surfaces with $\mathrm{ZnO}$ urchins (both seeded and unseeded, with $12 \mathrm{~h}$ growth time) were superhydrophilic, with a water droplet placed on these surfaces spreading completely and showing a water contact angle $\theta \sim 0^{\circ}$ (Table S1). They became superhydrophobic after overnight silanization (Table S1) with an apparent water contact angle $\theta \sim 159^{\circ} \pm 1.4^{\circ}$ (Figure 5a) and a contact angle hysteresis $\Delta \theta<7^{\circ}$ was observed. The water droplet exhibited a Cassie-Baxter state on the silanized $\mathrm{ZnO}$ urchin surface, which is evident from the high contact angle and low contact angle hysteresis. For comparison, Table S1 shows that bare Si and Si coated with a $20 \mathrm{~nm} \mathrm{ZnO}$ thin film exhibited hydrophilic behavior with apparent water contact angles $\theta \sim 36^{\circ}$ and $\sim 61^{\circ}$, respectively. 


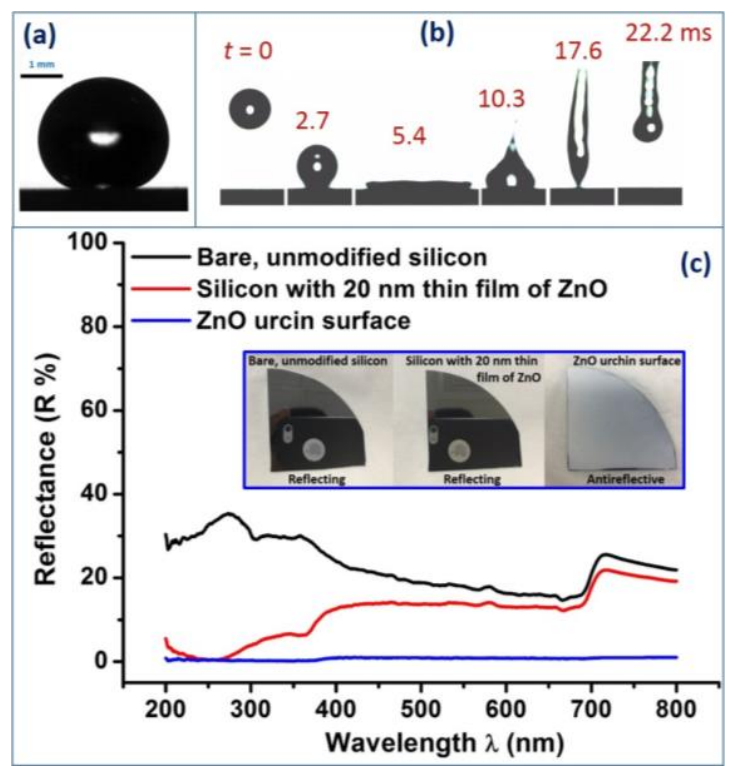

Figure 5. (a) Photograph of a $10 \mu \mathrm{L}$ water droplet on $\mathrm{ZnO}$ urchin-coated surface after silanization, with a contact angle $\theta \sim 159^{\circ} \pm 1.4^{\circ}$ (the scale bar is $1 \mathrm{~mm}$ ). Prior to silanization, the surface was highly hydrophilic, displaying complete wetting by water with $\theta \sim 0^{\circ}$ (Table S1). (b) High-speed camera images of a $10 \mu \mathrm{L}$ droplet bouncing off the superhydrophobic $\mathrm{ZnO}$ urchin surface, with a contact time of $15.3 \mathrm{~ms}$. (c) Reflectance from the $\mathrm{ZnO}$ urchin surface compared to the two control surfaces in the wavelength range $\lambda=200-800 \mathrm{~nm}$. The $\mathrm{ZnO}$ urchin surface was found to be the most anti-reflective with reflectance $\mathrm{R}<1 \%$ over the whole wavelength range. The inset shows the highly reflective bare $\mathrm{Si}$ and $\mathrm{Si}$ with $20 \mathrm{~nm} \mathrm{ZnO}$ film (with the reflection of the iPhone used to take the photo clearly visible), in contrast to the anti-reflective characteristic of the $\mathrm{ZnO}$ urchin surface.

To further demonstrate the superhydrophobicity in dynamic conditions, a $10 \mu \mathrm{L}$ water droplet was allowed to fall on the silanized $\mathrm{ZnO}$ urchin surface from a height of $7 \mathrm{~cm}$ with a Weber number $W e=\frac{\rho V^{2} D_{w}}{\gamma}=49$, where $\rho=1 \mathrm{~g} \mathrm{~cm}^{-3}$ is the density of water, $V=\sqrt{2 g h}=1.17 \mathrm{~m} \mathrm{~s}^{-1}$ the impact velocity of the falling droplet, $\gamma=73.8 \mathrm{mN} \mathrm{m}^{-1}$ the surface tension of water, and $D_{\mathrm{w}}=2.67 \mathrm{~mm}$ the diameter of droplet (Table S1). The dynamic process was captured using a high-speed camera with a 10,000 frames per second (fps) capture rate. The water droplet bounced off the superhydrophic surface completely without leaving any visible residues, with a droplet-substrate contact time of $15.3 \mathrm{~ms}$ (Figure $5 \mathrm{~b}$ and Video S1) which is close to the theoretical contact time $\left(\left(\frac{\rho D_{w}^{3}}{\gamma}\right)^{1 / 2}=16.25 \mathrm{~ms}\right)$ for a water droplet on a superhydrophobic surface [63].

In addition, the $\mathrm{ZnO}$ urchin coated surface also demonstrated anti-reflective behavior. Figure $5 \mathrm{c}$ showing $<1 \%$ reflectance $(R)$ over the wavelength range $\lambda=200-800 \mathrm{~nm}$ on the urchin surface, compared to two control samples (bare Si and Si with $20 \mathrm{~nm} \mathrm{ZnO}$ thin film). There have been previous reports on fabrication of nanostructured anti-reflective surfaces [6,11,64-70]. Different techniques such as dry etching, wet etching, metal assisted etching, nanoimprint lithography, etching using $\mathrm{O}_{2}$ plasma and inductively coupled plasma, optical lithography followed by etching etc. [71] have been used to fabricate such surfaces on silicon, polymers, and glass to achieve low reflectance. In comparison, the fabrication method we used to achieve low reflectance $(R<1 \%)$ was simple, with the synthesis undertaken at room temperature without the need for sophisticated instrumentation.

To evaluate the bacterial interaction with the fabricated $\mathrm{ZnO}$ urchins on the seeded Si surface, it was submerged in $2 \mathrm{~mL}$ E. coli culture in phosphate-buffered saline (PBS) for $24 \mathrm{~h}$ and then imaged with SEM. This was compared with two control samples: unmodified bare Si and Si with a $20 \mathrm{~nm}$ sputtered ZnO film (Figure S13). SEM images in Figure 6a (see also Table S2) showed bacteria growth on the control surfaces; in contrast, no bacterium was observed on the $\mathrm{ZnO}$ nanostructured 
surface (Figure $6 \mathrm{c}, \mathrm{d}$ ). In addition, the SEM analysis revealed a change in the morphology of the $\mathrm{ZnO}$ urchins (inset in Figure 6c): after $24 \mathrm{~h}$ immersion in the E. coli culture, the spiky urchin structure was transformed into a hexagonal pyramid structure (see Figure S14a). This can be attributed to the formation of sodium zinc phosphate hydrate $\left(\mathrm{NaZn}-\mathrm{PO}_{4} \cdot \mathrm{H}_{2} \mathrm{O}\right)[72]$ due to the reaction between $\mathrm{ZnO}$ urchins and the PBS (cf. XRD data in Figure S14b). ZnO is known to exhibit antimicrobial efficacy [15-19], killing bacteria and prohibiting bacterial growth on its surface via release of $\mathrm{Zn}^{2+}$ ions which solicit generation of reactive oxygen species (ROS). A number of naturally occurring surfaces bearing spiky nanotextures (e.g., cicada wings, dragonfly wings, and gecko skin) have been reported to exhibit bactericidal efficacy, attributed to puncturing or stretching of the bacterial membrane, although the detailed mechanisms remain to be fully understood [3,11,73-76]. Hence, we suggest that the $\mathrm{ZnO}$ urchin surfaces could prevent bacterial growth by combining synergistically the inherent chemical activity of $\mathrm{ZnO}$ and the spiky morphology of the urchins that inhibit the bacteria from colonizing on the surface of the $\mathrm{ZnO}$ urchins $[18,77-79]$. The sharp topography of the nanoneedles is particularly effective in disrupting the bacterial cell wall by imparting localized stress on the bacterial membrane [80]. There are previous reports on reduced bacterial adhesion on superhydrophobic surfaces [81-84] where the antiwetting property of the surface plays a crucial role in the interaction of the bacteria with the surface; whereas our fabricated $\mathrm{ZnO}$ urchin surfaces exhibited bacteriophobic behavior in a hydrophilic state (with a water contact angle $\theta \sim 0^{\circ}$ ).

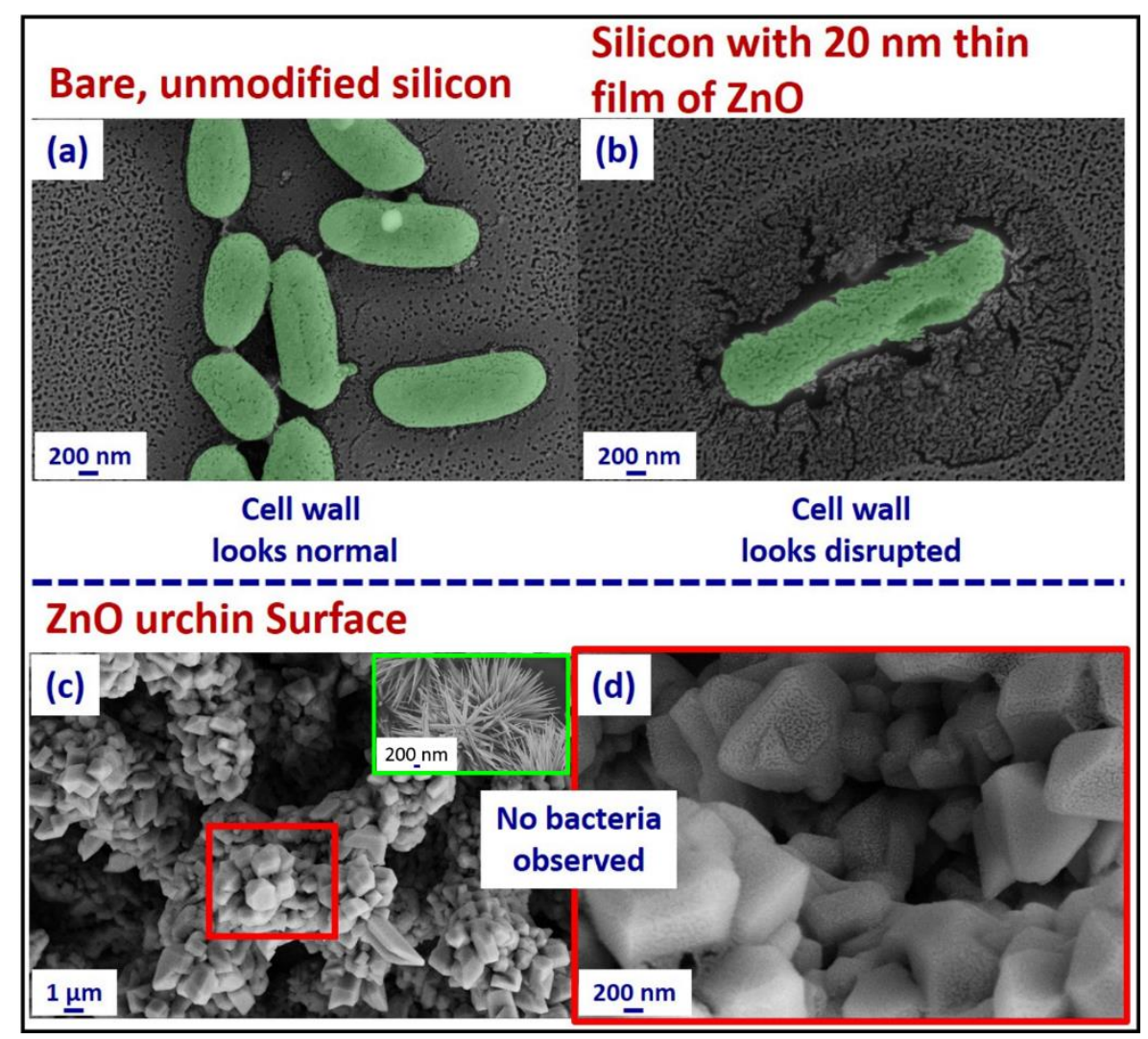

Figure 6. Representative SEM images of E. coli (false-colored green) on different surfaces after $24 \mathrm{~h}$ of bacterial culture: (a) bare, unmodified silicon, (b) silicon with a $20 \mathrm{~nm}$ thin film of $\mathrm{ZnO}$, and (c,d) $\mathrm{ZnO}$ urchin surface. Inset in (c) shows the morphology of the $\mathrm{ZnO}$ urchin before bacterial culture on the urchin surface.

\section{Conclusions}

In summary, $\mathrm{ZnO}$ urchin structures were fabricated via a simple method involving submergence of a substrate ( $\mathrm{Si}$, PDMS, glass, or $\mathrm{Cu})$ in an alkaline aqueous zincate ion $\left(\mathrm{Zn}(\mathrm{OH})_{4}{ }^{2-}\right)$ solution at 
room temperature $\left(\sim 20^{\circ} \mathrm{C}\right)$. On the $\mathrm{Si}$ substrate seeded with $\mathrm{ZnO}$ nanocrystals, we observed $\mathrm{ZnO}$ urchin structures atop vertically aligned $\mathrm{ZnO}$ nanoneedles. The urchins consisted of densely packed, $\mu \mathrm{m}$-long spiky $\mathrm{ZnO}$ nanoneedles radiating from the urchin center, with a tapering angle of $\sim 10^{\circ}$. The growth kinetics of the $\mathrm{ZnO}$ surface nanostructures were studied by time resolved SEM, revealing that the urchin morphology emerged at $\sim 3 \mathrm{~h}$ reaction time with a small number of tapered nanoneedles. The nanoneedle density and length then progressively increased with the reaction time. On the seeded Si substrate, a primary growth step of the vertical $\mathrm{ZnO}$ nanoneedles was identified preceding the secondary urchin growth. The $\mathrm{ZnO}$ urchin coated surface exhibited anti-reflective properties, reducing the reflectance to less than $1 \%$. It was highly hydrophilic, with a water contact angle of $\sim 0^{\circ}$; after silanization, it exhibited superhydrophobicity with a water contact angle of $159^{\circ}$ and hysteresis smaller than $7^{\circ}$. In addition, its dynamic hydrophobicity was demonstrated by the bouncing-off of a water drop as captured by a high-speed camera, with a resident time of $15.9 \mathrm{~ms}$. Furthermore, the $\mathrm{ZnO}$ urchin surface showed bacteriophobic behavior, as compared to the control Si and $\mathrm{ZnO}$-coated surfaces, with no bacterium colonization observed on the surface after $24 \mathrm{~h}$ incubation in E. coli. This simple method for preparing $\mathrm{ZnO}$ urchins with the unique morphology of tapered nanoneedles, and its ready adaptability to different surfaces (including polymers), may open new routes for the fabrication of multifunctional $\mathrm{ZnO}$ nanostructured surfaces.

Supplementary Materials: The following are available online at http://www.mdpi.com/2504-5377/2/4/74/s1: Figure S1, process flow of the fabrication of $\mathrm{ZnO}$ nanostructures on seeded silicon substrates at near room temperature; Figure S2, SEM images of a silicon substrate seeded with $\mathrm{ZnO}$ nanoislands in $5 \mathrm{mM}$ zinc acetate dihydrate solution (dipping $\times 5$ times and annealed at $300{ }^{\circ} \mathrm{C}$ for $30 \mathrm{~min}$ ); Figure S3, nanoneedle dimension measurement using ImageJ software. The values in the main text were averaged from 50 different needles, with the measurements of different parameters at each single needle repeated 5 times; Figure S4, size distribution from ImageJ analysis of the nanoneedle tip diameter at the top $D_{t}$ urchins ranging from 7-30 nm with an average diameter of $D_{t}=13 \pm 7 \mathrm{~nm}$; Figure S5, length of the nanoneedles, L, in the urchin structure vs. growth time. The length of the nanoneedle was found to increase with respect to synthesis time. Stars in the figure show that for time points $0,0.5$ and $1 \mathrm{~h}$ there was no formation of urchin structures; Figure S6, (a) the angled view after $9 \mathrm{~h}$ growth, showing $\mathrm{ZnO}$ urchins on the top of highly, (b) oriented $\mathrm{ZnO}$ nanoneedles; Figure S7, representative FESEM images of the seeded silicon substrate post $12 \mathrm{~h}$ synthesis in the zincate solution; Figure S8, SEM images of seeded silicon substrates after growth in zincate solution at different time intervals. The density of $\mathrm{ZnO}$ nanourchins was found to increase with the increase synthesis time; Figure S9, SEM images of seeded silicon substrates after growth in zincate solution at different time intervals. $\mathrm{Zn}(\mathrm{OH})_{2}$ crystals were observed on the substrates for synthesis time $\mathrm{t}>3 \mathrm{~h}$; Figure S10, SEM images of $\mathrm{ZnO}$ urchins on a non-seeded silicon substrate, taken at different time intervals, (a) $3 \mathrm{~h}$, (b) $6 \mathrm{~h}$, (c) $9 \mathrm{~h}$, and (d) $12 \mathrm{~h}$. (e-h) show enlarged views of the square regions as labelled in $(a-d)$, respectively; Figure S11, XRD of $(a, b)$ seeded and $(c, d)$ unseeded silicon substrates after growth in the zincate solution at $20^{\circ} \mathrm{C}$ for $12 \mathrm{~h}$, with the $\mathrm{ZnO}$ and $\varepsilon-\mathrm{Zn}(\mathrm{OH})_{2}$ peaks indicated by ${ }^{*}$ and $\boldsymbol{\nabla}$, respectively, and the enlarged views shown on the right-hand side; Figure S12, optical image showing the loss in transparency after the formation of ZnO urchin/nanoneedles on the glass substrate; Figure S13, 12-well culture plate for pouring the bacterial suspension on different samples; Figure S14, (a) SEM and (b) XRD of the $\mathrm{ZnO}$ nanourchin surface $24 \mathrm{~h}$ after pouring the bacterial culture. Formation of sodium zinc phosphate hydrate $\left(\mathrm{NaZn}-\mathrm{PO}_{4} \cdot \mathrm{H}_{2} \mathrm{O}\right)$ was observed on the surface due to the reaction of $\mathrm{ZnO}$ with PBS leading to the change in morphology of the spiky ZnO nanowires; Table S1, apparent contact angles of a DI water droplet on different substrates; Table S2, SEM of E. coli on different substrates; Video S1, superhydrophobic ZnO urchin.

Author Contributions: A.T. and W.H.B. conceived and designed experiments; A.T. and P.W. synthesized and characterized the ZnO urchins; A.T., S.S., D.N. and P.S. performed experiments on anti-reflectivity, E. coli colonization, and dynamic superhydrophobicity of the urchin surfaces; P.W., O.B. and W.H.B. performed synchrotron XRD measurements. All authors contributed to data analysis and manuscript writing.

Funding: A.T. acknowledges funding from the British Council, United Kingdom and Department of Biotechnology, Government of India through the Newton-Bhabha PhD fellowship program. P.W. acknowledges funding from the UK Engineering and Physical Sciences Research Council (EPSRC) through the Bristol Centre for Functional Nanomaterials (BCFN, grant no. EP/G036780/1). P.S. would like to thank the Ministry of Electronics and Information Technology, Government of India for their financial support. D.N. acknowledges funding from the Department of Biotechnology-Indian Institute of Science partnership program. W.H.B. would like to acknowledge funding from the EPSRC (EP/H034862/1 and Building Global Engagement in Research (BGER)), European Cooperation in Science and Technology (CMST COST) Action CM1101 “Colloidal Aspects of Nanoscience for Innovative Processes and Materials", and Marie Curie Initial Training Network (MCITN) on "Soft, Small, and Smart: Design, Assembly, and Dynamics of Novel Nanoparticles for Novel Industrial Applications" (NanoS3; FP7 Grant No. 290251). We acknowledge the beamline BM28 at the European Synchrotron Radiation Facility (a UK EPSRC funded facility) for beam time and the staff there for their help. 
Conflicts of Interest: The authors declare no conflicts of interest.

\section{References}

1. Tang, P.; Zhang, W.; Wang, Y.; Zhang, B.; Wang, H.; Lin, C.; Zhang, L. Effect of Superhydrophobic Surface of Titanium on Staphylococcus aureus Adhesion. J. Nanomater. 2011, 2011, 1-8. [CrossRef]

2. Fadeeva, E.; Truong, V.K.; Stiesch, M.; Chichkov, B.N.; Crawford, R.J.; Wang, J.; Ivanova, E.P. Bacterial retention on superhydrophobic titanium surfaces fabricated by femtosecond laser ablation. Langmuir 2011, 27, 3012-3019. [CrossRef] [PubMed]

3. Ivanova, E.P.; Hasan, J.; Webb, H.K.; Truong, V.K.; Watson, G.S.; Watson, J.A.; Baulin, V.A.; Pogodin, S.; Wang, J.Y.; Tobin, M.J.; et al. Natural Bactericidal Surfaces: Mechanical Rupture of Pseudomonas aeruginosa Cells by Cicada Wings. Small 2012, 8, 2489-2494. [CrossRef] [PubMed]

4. Pogodin, S.; Hasan, J.; Baulin, V.A.; Webb, H.K.; Truong, V.K.; Phong Nguyen, T.H.; Boshkovikj, V.; Fluke, C.J.; Watson, G.S.; Watson, J.A.; et al. Biophysical Model of Bacterial Cell Interactions with Nanopatterned Cicada Wing Surfaces. Biophys. J. 2013, 104, 835-840. [CrossRef] [PubMed]

5. Yao, C.; Webster, T.J.; Hedrick, M. Decreased bacteria density on nanostructured polyurethane. J. Biomed. Mater. Res. Part A 2014, 102, 1823-1828. [CrossRef] [PubMed]

6. Chattopadhyay, S.; Huang, Y.F.; Jen, Y.J.; Ganguly, A.; Chen, K.H.; Chen, L.C. Anti-reflecting and photonic nanostructures. Mater. Sci. Eng. R Rep. 2010, 69, 1-35. [CrossRef]

7. Yamada, N.; Kim, O.N.; Tokimitsu, T.; Nakai, Y.; Masuda, H. Optimization of anti-reflection moth-eye structures for use in crystalline silicon solar cells. Prog. Photovolt. Res. Appl. 2011, 19, 134-140. [CrossRef]

8. Park, H.; Shin, D.; Kang, G.; Baek, S.; Kim, K.; Padilla, W.J. Broadband optical antireflection enhancement by integrating antireflective nanoislands with silicon nanoconical-frustum arrays. Adv. Mater. 2011, 23, 5796-5800. [CrossRef] [PubMed]

9. Park, K.-C.; Choi, H.J.; Chang, C.-H.; Cohen, R.E.; McKinley, G.H.; Barbastathis, G. Nanotextured Silica Surfaces with Robust Superhydrophobicity and Omnidirectional Broadband Supertransmissivity. ACS Nano 2012, 6, 3789-3799. [CrossRef] [PubMed]

10. Zhang, D.; Yu, W.; Hao, D.; Li, L.; Liu, H.; Lu, Z. Functional nanostructured surfaces in hybrid sol-gel glass in large area for antireflective and super-hydrophobic purposes. J. Mater. Chem. 2012, 22, 17328-17331. [CrossRef]

11. Tripathy, A.; Sreedharan, S.; Bhaskarla, C.; Majumdar, S.; Peneti, S.K.; Nandi, D.; Sen, P. Enhancing the Bactericidal Efficacy of Nanostructured Multifunctional Surface Using an Ultrathin Metal Coating. Langmuir 2017, 33, 12569-12579. [CrossRef]

12. Zhang, Y.; Ram, M.K.; Stefanakos, E.K.; Goswami, D.Y. Synthesis, characterization, and applications of ZnO nanowires. J. Nanomater. 2012, 2012, 1-22. [CrossRef]

13. Jones, F.; Tran, H.; Lindberg, D.; Zhao, L.; Hupa, M. Thermal stability of zinc compounds. Energy Fuels 2013, 27, 5663-5669. [CrossRef]

14. Makarona, E.; Athanassiou, B.; Prionistis, C.; Tegou, E.; Tsamis, C. A cost-efficient solution-based process for the development of $\mathrm{ZnO}$ nanostructures: A comprehensive study of the role of the seeding layer formation conditions. Procedia Eng. 2015, 120, 447-450. [CrossRef]

15. Kumar, R.; Umar, A.; Kumar, G.; Nalwa, H.S. Antimicrobial properties of ZnO nanomaterials: A review. Ceram. Int. 2017, 43, 3940-3961. [CrossRef]

16. Xie, Y.; He, Y.; Irwin, P.L.; Jin, T.; Shi, X. Antibacterial activity and mechanism of action of zinc oxide nanoparticles against Campylobacter jejuni. Appl. Environ. Microbiol. 2011, 77, 2325-2331. [CrossRef]

17. Sirelkhatim, A.; Mahmud, S.; Seeni, A.; Kaus, N.H.M.; Ann, L.C.; Bakhori, S.K.M.; Hasan, H.; Mohamad, D. Review on zinc oxide nanoparticles: Antibacterial activity and toxicity mechanism. Nano-Micro Lett. 2015, 7, 219-242. [CrossRef]

18. Tam, K.H.; Djurišić, A.B.; Chan, C.M.N.; Xi, Y.Y.; Tse, C.W.; Leung, Y.H.; Chan, W.K.; Leung, F.C.C.; Au, D.W.T. Antibacterial activity of $\mathrm{ZnO}$ nanorods prepared by a hydrothermal method. Thin Solid Films 2008, 516, 6167-6174. [CrossRef]

19. Abinaya, C.; Mayandi, J.; Osborne, J.; Frost, M.; Ekstrum, C.; Pearce, J.M. Inhibition of growth of S. epidermidis by hydrothermally synthesized $\mathrm{ZnO}$ nanoplates. Mater. Res. Express 2017, 4, 075401. [CrossRef] 
20. Li, Z.; Yang, R.; Yu, M.; Bai, F.; Li, C.; Wang, Z.L.; Li, Z.; Yang, R.; Yu, M.; Bai, F.; et al. Cellular Level Biocompatibility and Biosafety of ZnO Nanowires Cellular Level Biocompatibility and Biosafety of ZnO Nanowires. J. Phys. Chem. C 2008, 112, 20114-20117. [CrossRef]

21. Li, P.; Liu, H.; Lu, B.; Wei, Y. Formation mechanism of $1 \mathrm{D} \mathrm{ZnO}$ nanowhiskers in aqueous solution. J. Phys. Chem. C 2010, 114, 21132-21137. [CrossRef]

22. McBride, R.A.; Kelly, J.M.; McCormack, D.E. Growth of well-defined ZnO microparticles by hydroxide ion hydrolysis of zinc salts. J. Mater. Chem. 2003, 13, 1196-1201. [CrossRef]

23. Wang, J.; Hou, S.; Zhang, L.; Chen, J.; Xiang, L. Ultra-rapid formation of ZnO hierarchical structures from dilution-induced supersaturated solutions. CrystEngComm 2014, 16, 7115-7123. [CrossRef]

24. You, T.; Yan, J.; Zhang, Z.; Li, J.; Tian, J.; Yun, J.; Zhao, W. Fabrication and optical properties of needle-like $\mathrm{ZnO}$ array by a simple hydrothermal process. Mater. Lett. 2012, 66, 246-249. [CrossRef]

25. Safa, S. Enhanced UV-detection properties of carbon nanotube impregnated ZnO nanourchins. Optik (Stuttg) 2015, 126, 2194-2198. [CrossRef]

26. Ko, Y.H.; Yu, J.S. Tunable growth of urchin-shaped $\mathrm{ZnO}$ nanostructures on patterned transparent substrates. CrystEngComm 2012, 14, 5824-5829. [CrossRef]

27. Imani, R.; Drašler, B.; Kononenko, V.; Romih, T.; Eleršič, K.; Jelenc, J.; Junkar, I.; Remškar, M.; Drobne, D.; Kralj-Iglič, V.; et al. Growth of a Novel Nanostructured ZnO Urchin: Control of Cytotoxicity and Dissolution of the ZnO Urchin. Nanoscale Res. Lett. 2015, 10, 441. [CrossRef]

28. Banerjee, D.; Lao, J.Y.; Wang, D.Z.; Huang, J.Y.; Steeves, D.; Kimball, B.; Ren, Z.F. Synthesis and photoluminescence studies on $\mathrm{ZnO}$ nanowires. Nanotechnology 2004, 15, 404-409. [CrossRef]

29. Wasik, P.; Redeker, C.; Dane, T.G.; Seddon, A.M.; Wu, H.; Briscoe, W.H. Hierarchical Surface Patterns upon Evaporation of a ZnO Nanofluid Droplet: Effect of Particle Morphology. Langmuir 2018, 34, 1645-1654. [CrossRef]

30. Wu, H.; Chen, L.X.; Zeng, X.Q.; Ren, T.H.; Briscoe, W.H. Self-assembly in an evaporating nanofluid droplet: Rapid transformation of nanorods into 3D fibre network structures. Soft Matter 2014, 10, 5243-5248. [CrossRef]

31. Greene, L.E.; Law, M.; Tan, D.H.; Montano, M.; Goldberger, J.; Somorjai, G.; Yang, P. General route to vertical $\mathrm{ZnO}$ nanowire arrays using textured $\mathrm{ZnO}$ seeds. Nano Lett. 2005, 5, 1231-1236. [CrossRef] [PubMed]

32. Wang, G.; Li, Z.; Li, M.; Feng, Y.; Li, W.; Lv, S.; Liao, J. Synthesizing vertical porous ZnO nanowires arrays on $\mathrm{Si} /$ ITO substrate for enhanced photocatalysis. Ceram. Int. 2018, 44, 1291-1295. [CrossRef]

33. Gacusan, J.; Kobayashi, N.P.; Sanghadasa, M.; Meyyappan, M. Controlled growth of vertical ZnO nanowires on copper substrate. Appl. Phys. Lett. 2013, 102, 083105.

34. Wu, C.; Shen, L.; Yu, H.; Huang, Q.; Zhang, Y.C. Synthesis of Sn-doped ZnO nanorods and their photocatalytic properties. Mater. Res. Bull. 2011, 46, 1107-1112. [CrossRef]

35. Solís-Pomar, F.; Martínez, E.; Meléndrez, M.F.; Pérez-Tijerina, E. Growth of vertically aligned ZnO nanorods using textured ZnO films. Nanoscale Res. Lett. 2011, 6, 524. [CrossRef] [PubMed]

36. Gurav, A.B.; Latthe, S.S.; Vhatkar, R.S.; Lee, J.G.; Kim, D.Y.; Park, J.J.; Yoon, S.S. Superhydrophobic surface decorated with vertical $\mathrm{ZnO}$ nanorods modified by stearic acid. Ceram. Int. 2014, 40, 7151-7160. [CrossRef]

37. Lee, Y.; Zhang, Y.; Ng, S.L.G.; Kartawidjaja, F.C.; Wang, J. Hydrothermal growth of vertical ZnO nanorods. J. Am. Ceram. Soc. 2009, 92, 1940-1945. [CrossRef]

38. Wasik, P.; Seddon, A.M.; Wu, H.; Briscoe, W.H. Dendritic surface patterns from Bénard-Marangoni instabilities upon evaporation of a reactive $\mathrm{ZnO}$ nanofluid droplet: A fractal dimension analysis. J. Colloid Interface Sci. 2019, 536, 493-498. [CrossRef]

39. Wu, H.; Briscoe, W.H. Morphogenesis of polycrystalline dendritic patterns from evaporation of a reactive nanofluid sessile drop. Phys. Rev. Mater. 2018, 2, 045601. [CrossRef]

40. Hu, J.Q.; Li, Q.; Meng, X.M.; Lee, C.S.; Lee, S.T. Thermal reduction route to the fabrication of coaxial Zn/ZnO nanocables and $\mathrm{ZnO}$ nanotubes. Chem. Mater. 2003, 15, 305-308. [CrossRef]

41. Riaz, M.; Fulati, A.; Amin, G.; Alvi, N.H.; Nur, O.; Willander, M. Buckling and elastic stability of vertical ZnO nanotubes and nanorods. J. Appl. Phys. 2009, 106, 034309. [CrossRef]

42. Sun, Y.; Riley, D.J.; Ashfbld, M.N.R. Mechanism of ZnO nanotube growth by hydrothermal methods on $\mathrm{ZnO}$ film-coated Si substrates. J. Phys. Chem. B 2006, 110, 15186-15192. [CrossRef] 
43. Katwal, G.; Paulose, M.; Rusakova, I.A.; Martinez, J.E.; Varghese, O.K. Rapid Growth of Zinc Oxide Nanotube-Nanowire Hybrid Architectures and Their Use in Breast Cancer-Related Volatile Organics Detection. Nano Lett. 2016, 16, 3014-3021. [CrossRef]

44. Wang, Y.; Cui, Z. Synthesis and photoluminescence of well aligned $\mathrm{ZnO}$ nanotube arrays by a simple chemical solution method. J. Phys. Conf. Ser. 2009, 152, 012021. [CrossRef]

45. Wahab, R.; Ansari, S.G.; Kim, Y.S.; Seo, H.K.; Kim, G.S.; Khang, G.; Shin, H.S. Low temperature solution synthesis and characterization of ZnO nano-flowers. Mater. Res. Bull. 2007, 42, 1640-1648. [CrossRef]

46. Gokarna, A.; Parize, R.; Kadiri, H.; Nomenyo, K.; Patriarche, G.; Miska, P.; Lerondel, G. Highly crystalline urchin-like structures made of ultra-thin zinc oxide nanowires. RSC Adv. 2014, 4, 47234-47239. [CrossRef]

47. Hieu, H.N.; Vuong, N.M.; Jung, H.; Jang, D.M.; Kim, D.; Kim, H.; Hong, S.-K. Optimization of a zinc oxide urchin-like structure for high-performance gas sensing. J. Mater. Chem. 2012, 22, 1127-1134. [CrossRef]

48. Taheri, M.; Abdizadeh, H.; Golobostanfard, M.R. Formation of urchin-like ZnO nanostructures by sol-gel electrophoretic deposition for photocatalytic application. J. Alloys Compd. 2017, 725, 291-301. [CrossRef]

49. Shen, G.; Bando, Y.; Lee, C.J. Synthesis and evolution of novel hollow ZnO urchins by a simple thermal evaporation process. J. Phys. Chem. B 2005, 109, 10578-10583. [CrossRef] [PubMed]

50. Elias, J.; Bechelany, M.; Utke, I.; Erni, R.; Hosseini, D.; Michler, J.; Philippe, L. Urchin-inspired zinc oxide as building blocks for nanostructured solar cells. Nano Energy 2012, 1, 696-705. [CrossRef]

51. Newton, M.C.; Warburton, P.A. ZnO tetrapod nanocrystals. Mater. Today 2007, 10, 50-54. [CrossRef]

52. Modi, G. Zinc oxide tetrapod: A morphology with multifunctional applications. Adv. Nat. Sci. Nanosci. Nanotechnol. 2015, 6, 033002. [CrossRef]

53. Neykova, N.; Brož, A.; Remeš, Z.; Hruška, K.; Kalbáčová, M.; Kromka, A.; Vaněček, M. ZnO hedgehog-like structures for control cell cultivation. Appl. Surf. Sci. 2012, 258, 3485-3489. [CrossRef]

54. Bhaskarla, C.; Das, M.; Verma, T.; Kumar, A.; Mahadevan, S.; Nandi, D. Roles of Lon protease and its substrate MarA during sodium salicylate-mediated growth reduction and antibiotic resistance in Escherichia coli. Microbiology 2016, 162, 764-776. [CrossRef]

55. Sutton, S. Measurement of microbial cells by optical density. J. Valid. Technol. 2011, 17, 46-49.

56. Schneider, C.A.; Rasband, W.S.; Eliceiri, K.W. NIH Image to ImageJ: 25 years of image analysis. Nat. Methods 2012, 9, 671-675. [CrossRef] [PubMed]

57. Ashiotis, G.; Deschildre, A.; Nawaz, Z.; Wright, J.P.; Karkoulis, D.; Picca, F.E.; Kieffer, J. The fast azimuthal integration Python library: PyFAI. J. Appl. Crystallogr. 2015, 48, 510-519. [CrossRef]

58. De Gennes, P.-G.; Brochard-Wyart, F.; Quéré, D. Capillarity and Wetting Phenomena; Springer: New York, NY, USA, 2004; ISBN 978-1-4419-1833-8.

59. Efroimsky, M.; Gamberg, L.; Gitman, D.; Lazarian, A.; Smirnov, B. Wetting of Real Surfaces: De Gruyter Studies in Mathematical Physics 19; Walter de Gruyter GmbH: Berlin, Germany, 2013; ISBN 978-311-02-58-530.

60. Mittal, K. Contact Angle Wettability and Adhesion; Koninklijke Brill NV: Leiden, The Netherlands, 2009; ISBN 978-90-04-16932-6.

61. Wu, X.; Bai, H.; Li, C.; Lu, G.; Shi, G. Controlled one-step fabrication of highly oriented ZnO nanoneedle/nanorods arrays at near room temperature. Chem. Commun. 2006, 15, 1655-1657. [CrossRef]

62. Xu, S.; Wang, Z.L. One-dimensional ZnO nanostructures: Solution growth and functional properties. Nano Res. 2011, 4, 1013-1098. [CrossRef]

63. Clanet, C.; Béguin, C.; Richard, D.; Quéré, D. Maximal deformation of an impacting drop. J. Fluid Mech. 2004, 517, 199-208. [CrossRef]

64. Han, Z.W.; Wang, Z.; Feng, X.M.; Li, B.; Mu, Z.Z.; Zhang, J.Q.; Niu, S.C.; Ren, L.Q. Antireflective surface inspired from biology: A review. Biosurface Biotribol. 2016, 2, 137-150. [CrossRef]

65. Diao, Z.; Dirks, J.-H.; Spatz, J. Bio-inspired, nanostructured anti-reflective surfaces for laser applications. In Proceedings of the 2016 Conference on Lasers and Electro-Optics (CLEO), San Jose, CA, USA, 5-10 June 2016.

66. Boden, S.A.; Bagnall, D.M. Tunable reflection minima of nanostructured antireflective surfaces. Appl. Phys. Lett. 2008, 93, 133108. [CrossRef]

67. Zada, I.; Zhang, W.; Sun, P.; Imtiaz, M.; Abbas, W.; Zhang, D. Multifunctional, Angle Dependent Antireflection, and Hydrophilic Properties of $\mathrm{SiO}_{2}$ Inspired by Nano-Scale Structures of Cicada Wings. Appl. Phys. Lett. 2017, 111, 153701. [CrossRef] 
68. Chen, Y.C.; Huang, Z.S.; Yang, H. Cicada-Wing-Inspired Self-Cleaning Antireflection Coatings on Polymer Substrates. ACS Appl. Mater. Interfaces 2015, 7, 25495-25505. [CrossRef] [PubMed]

69. Morikawa, J.; Ryu, M.; Seniutinas, G.; Balčytis, A.; Maximova, K.; Wang, X.; Zamengo, M.; Ivanova, E.P.; Juodkazis, S. Nanostructured antireflective and thermoisolative cicada wings. Langmuir 2016, 32, 4698-4703. [CrossRef] [PubMed]

70. Tripathy, A.; Sen, P. Dragonfly wing inspired multifunctional antireflective superhydrophobic surfaces. In Proceedings of the 2016 3rd International Conference on Emerging Electronics (ICEE), Mumbai, India, 27-30 December 2016; pp. 1-3.

71. Cai, J.; Qi, L. Recent advances in antireflective surfaces based on nanostructure arrays. Mater. Horiz. 2015, 2, 37-53. [CrossRef]

72. Liu, S.; Killen, E.; Lim, M.; Gunawan, C.; Amal, R. The effect of common bacterial growth media on zinc oxide thin films: Identification of reaction products and implications for the toxicology of $\mathrm{ZnO}$. RSC Adv. 2014, 4, 4363-4370. [CrossRef]

73. Tripathy, A.; Sen, P.; Su, B.; Briscoe, W.H. Natural and bioinspired nanostructured bactericidal surfaces. Adv. Colloid Interface Sci. 2017, 248, 85-104. [CrossRef]

74. Ivanova, E.P.; Hasan, J.; Webb, H.K.; Gervinskas, G.; Juodkazis, S.; Truong, V.K.; Wu, A.H.F.; Lamb, R.N.; Baulin, V.A.; Watson, G.S.; et al. Bactericidal activity of black silicon. Nat. Commun. 2013, 4, 2838. [CrossRef]

75. Li, X.; Cheung, G.S.; Watson, G.S.; Watson, J.A.; Lin, S.; Schwarzkopf, L.; Green, D.W. The nanotipped hairs of gecko skin and biotemplated replicas impair and/or kill pathogenic bacteria with high efficiency. Nanoscale 2016, 8, 18860-18869. [CrossRef]

76. Tripathy, A.; Pahal, S.; Mudakavi, R.J.; Raichur, A.M.; Varma, M.M.; Sen, P. Impact of Bioinspired Nanotopography on the Antibacterial and Antibiofilm Efficacy of Chitosan. Biomacromolecules 2018, 19, 1340-1346. [CrossRef] [PubMed]

77. Zanni, E.; Bruni, E.; Chandraiahgari, C.R.; De Bellis, G.; Santangelo, M.G.; Leone, M.; Bregnocchi, A.; Mancini, P.; Sarto, M.S.; Uccelletti, D. Evaluation of the antibacterial power and biocompatibility of zinc oxide nanorods decorated graphene nanoplatelets: New perspectives for antibiodeteriorative approaches. J. Nanobiotechnol. 2017, 15, 57. [CrossRef] [PubMed]

78. Okyay, T.O.; Bala, R.K.; Nguyen, H.N.; Atalay, R.; Bayam, Y.; Rodrigues, D.F. Antibacterial properties and mechanisms of toxicity of sonochemically grown ZnO nanorods. RSC Adv. 2015, 5, 2568-2575. [CrossRef]

79. Rago, I.; Chandraiahgari, C.R.; Bracciale, M.P.; De Bellis, G.; Zanni, E.; Cestelli Guidi, M.; Sali, D.; Broggi, A.; Palleschi, C.; Sarto, M.S.; et al. Zinc oxide microrods and nanorods: Different antibacterial activity and their mode of action against Gram-positive bacteria. RSC Adv. 2014, 4, 56031-56040. [CrossRef]

80. Li, X.; Chen, T. Enhancement and suppression effects of a nanopatterned surface on bacterial adhesion. Phys. Rev. E 2016, 93, 052419. [CrossRef] [PubMed]

81. Zhang, X.; Wang, L.; Levänen, E. Superhydrophobic surfaces for the reduction of bacterial adhesion. RSC Adv. 2013, 3, 12003-12020. [CrossRef]

82. Ma, J.; Sun, Y.; Gleichauf, K.; Lou, J.; Li, Q. Nanostructure on taro leaves resists fouling by colloids and bacteria under submerged conditions. Langmuir 2011, 27, 10035-10040. [CrossRef] [PubMed]

83. Truong, V.K.; Webb, H.K.; Fadeeva, E.; Chichkov, B.N.; Wu, A.H.F.; Lamb, R.; Wang, J.Y.; Crawford, R.J.; Ivanova, E.P. Air-directed attachment of coccoid bacteria to the surface of superhydrophobic lotus-like titanium. Biofouling 2012, 28, 539-550. [CrossRef]

84. Stallard, C.P.; McDonnell, K.A.; Onayemi, O.D.; O'Gara, J.P.; Dowling, D.P. Evaluation of protein adsorption on atmospheric plasma deposited coatings exhibiting superhydrophilic to superhydrophobic properties. Biointerphases 2012, 7, 31. [CrossRef]

(C) 2018 by the authors. Licensee MDPI, Basel, Switzerland. This article is an open access article distributed under the terms and conditions of the Creative Commons Attribution (CC BY) license (http:// creativecommons.org/licenses/by/4.0/). 